\title{
Pendampingan Program Pengayaan Ekstrakurikuler di SD/MI Bahagia, Wonokromo, Surabaya
}

\author{
Siti Ina Savira ${ }^{1 *}$, Muhammad Syafiq ${ }^{2}$, Damajanti Kusuma Dewi ${ }^{3}$, Desi Nurwidawati ${ }^{4}$ \\ 1,2,3,4 Jurusan Psikologi, Universitas Negeri Surabaya
}

A R T I C L E I N F O

Article history:

Received 15 Januari 2018

Received in revised form 09Februari 2018

Accepted 30 Maret 2018

Available online $22 \mathrm{Mei}$

2018

Kata Kunci:

kegiatan ekstrakurikuler, program pendampingan, pengayaan

Keywords:

extracurricular activities, advocacy, enrichment

\begin{abstract}
A B S T R A K
Artikel ini bertujuan untuk mendeskripsikan kegiatan pendampingan program pengayaan ekstrakurikuler di SD/MI Bahagia, Wonokromo, Surabaya. Pendampingan dilakukan setiap minggu selama dua bulan yaitu April hingga Mei 2017 pada hari Sabtu yang dilakukan oleh tim Peneliti dari Universitas Negeri Surabaya (Unesa) bersama dengan tim Bakti Psikologi mahasiswa Psikologi Unesa. Kegiatan pendampingan terdiri dari dua macam kegiatan, yaitu pemberian konsultasi kepada guru dan pemberian kegiatan ekstrakurikuler pada siswa. Dengan demikian, target kegiatan ini mencakup guru dan siswa di Sekolah SD/MI Bahagia. Sekolah SD/MI Bahagia secara khusus dipilih sebab memiliki latar belakang dan keterbatasan sosial-ekonomi yang unik. Pendampingan diberikan untuk meningkatkan keterampilan khusus dan kreativitas guru untuk merancang kegiatan tambahan untuk membantu siswa mengembangkan minat dan keterampilan khususnya pula. Berdasarkan kegiatan yang dilaksanakan, hasil menunjukkan meningkatnya keaktifan dan partisipasi siswa dalam kelas, serta meningkatnya keterampilan guru dalam memanfaatkan media untuk kegiatan ekstrakurikuler siswa. Hasil tersebut juga menunjukkan bahwa pemberian kegiatan ekstrakurikuler yang efektif, dapat berdampak positif pada kemampuan akademik siswa.
\end{abstract}

A B S T R A C T

This paper is aimed to describe extracurricular advocacy activity at Islamic Primary School Bahagia, Wonokromo, Surabaya. The advocacy was given every Saturday for 2 months from April to May 2017 which was delivered by the team of researchers of Universitas Negeri Surabaya (Unesa) along with team Bakti Psikologi of Psychology students of Unesa. There were two types of advocacy given that is providing consultation for teachers and delivering an extracurricular to students. This school is particularly chosen because it has a unique social-economy background and limitations. The advocacy provided was to improve teachers' soft-skills and creativity to be able to design supplementary activities to help students grow their interest and soft-skill as well. The result has shown not only an increase in students participation in classroom, but also teacher's ability to create media to provide supplementary activities for students. The result has also shown that providing effective extracurricular activities may have positive impact on student's academic ability.

\footnotetext{
* Corresponding author.

E-mail addresses: sitisavira@ unesa.ac.id (Siti Ina Savira)
} 


\section{Pendahuluan}

Permasalahan pendidikan sangat beragam dan banyak hal yang mempengaruhinya. Di antara faktor yang sangat penting dalam dunia pendidikan adalah kurikulum. Perlu adanya terobosan-terobosan baru dan upaya berkelanjutan dalam sistem pendidikan sehingga mampu meningkatkan mutu pendidikan melalui perbaikan dan pembenahan yang terus menerus dilakukan (Ubaidah,2014). Sekolah sebagai lembaga pendidikan formal membutuhkan dukungan dari pihak keluarga, lingkungan atau lembagalembaga pendidikan lainnya dalam membentuk generasi penerus bangsa yang berkualitas.

Sekolah Dasar Madrasah Ibtidaiyah Bahagia berlokasi di Jalan Gunung Sari I No.1, Sawunggaling, Wonokromo, Surabaya, merupakan sekolah swasta yang berada di bawah naungan Kementerian Agama. Sekolah ini memberi pendidikan secara gratis kepada anak-anak kurang mampu di sekitar Wonokromo, termasuk terminal Joyoboyo dan sekitarnya. Anak-anak tersebut rata-rata berasal dari golongan sosial ekonomi bawah, seperti pengamen, pemulung, serta berbagai pekerjaan lain tanpa penghasilan tetap.

Berdasarkan hasil wawancara dan observasi dapat diketahui setidaknya terdapat dua masalah utama mencakup permasalahan akademik dan non-akademik. Permasalahan akademik mencakup hal-hal sebagai berikut. Pertama, rendahnya partisipasi kedatangan ke sekolah. Sebagian siswa SD/MI Bahagia, seringkali membolos atau tidak hadir ke sekolah tanpa alasan ataupun pemberitahuan. Kedua, rendahnya pemahaman terhadap materi yang diberikan.

Adapun permasalahan non-akademik mencakup hal-hal sebagai berikut. Pertama adalah permasalahan sarana prasarana. Permasalahan ini merupakan salah satu hal yang sering dijadikan alasan oleh guru-guru sebagai penyebab sulitnya mengoptimalkan pelajaran. Pembelajaran lebih banyak dilakukan dengan cara konvensional dan klasikal, serta cenderung satu arah. Ruangan berukuran 15 x 6 meter diberi sekat tidak-permanen sehingga menjadi 3 ruangan kecil yang masing-masing difungsikan sebagai kelas. Dengan demikian, sulit untuk fokus pada penjelasan guru sebab suara dari 'ruang kelas' di sebelahnya sangat mengganggu. Sekolah juga tidak memiliki lapangan yang cukup untuk mengakomodir kegiatan outdoor. Kegiatan olahraga dilakukan di dalam kelas.

Kedua, permasalahan terkait sumber daya manusia; terbatasnya SDM yang dimiliki juga menyulitkan optimalisasi pembelajaran. Guru terdiri dari 3 orang, dimana salah satunya juga merangkap sebagai Kepala Sekolah. Keterbatasan kompetensi guru juga kerap menjadi masalah, dimana guru tampak kurang kreatif dalam menyampaikan pelajaran, kurang menguasai pelajaran, serta kurang dapat merespon dengan positif perilaku siswa. Berdasarkan hasil observasi, rendahnya kreativitas guru dalam memberikan materi pelajaran, sehingga terkesan monoton, serta kurangnya aktivitas tambahan yang mendukung pembelajaran akademik berdampak pada motivasi dan pemahaman siswa yang rendah. Metode pembelajaran yang diberikan sangat monoton, dimana pendekatan klasikal dengan ceramah satu arah menjadi satu-satunya metode mengajar. Metode tersebut kurang mengakomodir eksplorasi dan rasa ingin tahu siswa, serta tidak mendorong berkembangnya kemampuan berpikir yang lebih baik.

Ketiga, sikap orangtua ataupun lingkungan keluarga yang cenderung negatif terhadap sekolah. Berdasarkan hasil wawancara kepada guru, beberapa orangtua bahkan menjadi penyebab utama gagalnya siswa hadir ke sekolah. Latar belakang sosial ekonomi dianggap memiliki pengaruh besar, sebab sebagian siswa harus membantu orangtua mendapat penghasilan untuk menghidupi keluarga. Selain itu, lingkungan sosial tempat mereka tinggal kurang kondusif untuk mendukung perkembangan sosialemosional yang baik, sehingga permasalahan perilaku dan emosional juga kerap muncul pada siswa. Latar belakang pendidikan orangtua yang tergolong rendah juga mempengaruhi kurang optimalnya stimulasi bagi perkembangan kognitif dan sosial yang optimal.

Berdasarkan uraian di atas, dapat disimpulkan bahwa permasalahan utama yang dihadapi adalah sikap negatif siswa terhadap sekolah dan pembelajaran. Sedangkan permasalahan utama yang diduga sebagai penyebab dari permasalahan adalah rendahnya kreativitas dalam memberikan pengajaran, sikap negatif guru terhadap permasalahan perilaku siswa yang muncul, kurangnya kegiatan tambahan yang menstimulasi siswa, serta latar belakang sosial ekonomi keluarga yang berdampak pada sikap siswa terhadap sekolah dan pembelajaran. Penelitian menunjukkan bahwa pendekatan maupun sikap yang digunakan guru dalam kelas memiliki pengaruh besar terhadap sikap siswa terhadap pembelajaran (Gibson \& Chase, 2002; Wentzel, 1997). Demikian pula peran orangtua memiliki pengaruh signifikan terhadap motivasi dan kemampuan siswa menjalin hubungan sosial yang baik di sekolah (Wentzel, 1998).

Adapun kegiatan pengabdian (PKM) ini difokuskan pada masalah yang bisa langsung diintervensi, yaitu permasalahan pertama. Strategi pemecahan masalah yang disepakati untuk digunakan dalam kegiatan PKM ini adalah menggunakan permainan edukasi. Permainan edukasi merupakan kegiatan yang banyak disarankan untuk anak-anak sebab kegiatan ini memiliki karakteristik tertentu seperti, diikuti dengan sukarela, karena anak umumnya dengan senang hati mau terlibat, serta secara intrinsik mendorong tumbuhnya motivasi pada siswa (Rieber, 1996). Kegiatan bermain juga diyakini sebagai 
sebagai kegiatan yang alami dan produktif untuk melibatkan anak dalam berbagai kegiatan, terutama untuk mengajarkan strategi pemecahan masalah dan keterampilan kognitif lain (Ailwood, 2003; Rieber, 1996). Oleh sebab itu, kegiatan ini dipilih sebab dianggap sesuai untuk digunakan pada sekolah dengan permasalahan seperti yang telah diidentifikasi di atas.

Permainan edukasi dapat dilaksanakan dengan sarana prasarana terbatas yang dimiliki sekolah. Permainan ini juga dapat diterapkan atau digunakan ulang oleh guru setelah kegiatan PKM selesai, sebab sangat sederhana. Sedangkan alasan terakhir adalah dapat menjadi model atau contoh penerapan metode pembelajaran yang baik, yang diharapkan dapat menunjang peningkatan keterampilan (soft-skill) dan dapat mencapai tujuan kegiatan yaitu meningkatkan motivasi, kepercayaan diri, kerjasama tim, serta pengetahuan siswa yang menunjang prestasi akademiknya. Meningkatknya berbagai keterampilan softskill pada siswa diharapkan dapat membantu mengurangi permasalahan perilaku maupun emosional yang kerap muncul pada siswa

\section{Metode}

Kegiatan pendampingan terhadap guru dan siswa diberikan setiap hari Sabtu, sejak bulan April hingga Mei 2017. Kegiatan pendampingan mencakup dua kegiatan utama, yaitu konsultasi yang diberikan kepada guru-guru, dan pemberian kegiatan tambahan atau ekstrakurikuler pada siswa. Pemberian konsultasi dilakukan dengan dua cara, yaitu verbal, seperti mendiskusikan berbagai permasalahan siswa mencakup permasalahan akademik dan non-akademik, serta pendampingan dalam memberikan kegiatan tambahan bagi siswa. Kegiatan yang kedua, adalah pemberian kegiatan tambahan atau ekstrakurikuler, yang juga ditujukan sebagai bentuk modelling bagi guru-guru.

Adapun gambaran umum mengenai keterkaitan antara permasalahan dengan solusi yang ditawarkan dapat dilihat pada tabel 1.

Tabel 1. Keterkaitan masalah dengan solusi

\begin{tabular}{|c|c|c|c|}
\hline $\begin{array}{l}\text { Indikator } \\
\text { permasalahan }\end{array}$ & Permasalahan utama & Penyebab permasalahan & Solusi yang ditawarkan \\
\hline $\begin{aligned} & \text { Akademik } \\
& \text { 1. } \text { Rendahnya } \\
& \text { partisipasi } \\
& \text { kedatangan ke } \\
& \text { sekolah } \\
& 2 . \text { Rendahnya } \\
& \text { pemahaman } \\
& \text { terhadap } \\
& \text { materi } \\
& \text { Non-akademik } \text { Sarana- } \\
& \text { 1. } \text { prasarana yang } \\
& \text { minim } \\
& \text { 2. } \text { Pengajar yang } \\
& \text { terbatas dari } \\
& \text { segi jumlah } \\
& \text { maupun } \\
& \text { kualitas } \\
& \text { 3. } \text { Sikap negatif } \\
& \text { orangtua dan } \\
& \text { keluarga } \\
& \text { terhadap } \\
& \text { sekolah }\end{aligned}$ & $\begin{array}{l}\text { Sikap negatif siswa } \\
\text { terhadap sekolah dan } \\
\text { pembelajaran }\end{array}$ & 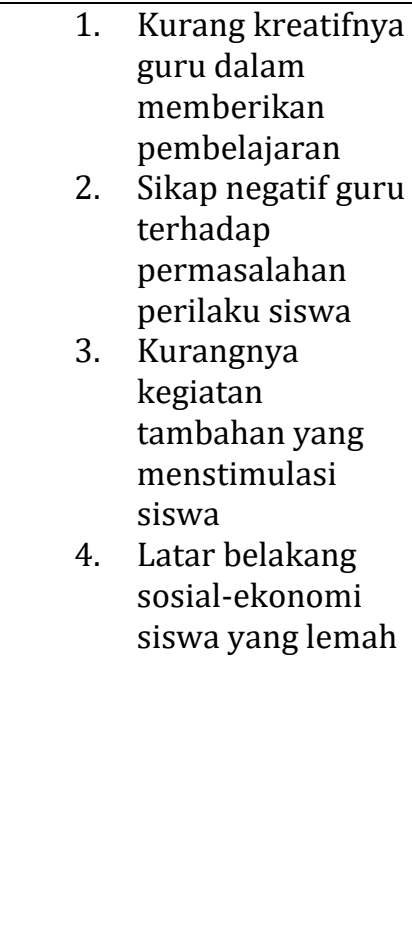 & $\begin{array}{l}\text { Memberikan } \\
\text { pendampingan kepada } \\
\text { guru dan siswa dalam } \\
\text { merancang dan } \\
\text { memberikan kegiatan } \\
\text { tambahan atau } \\
\text { ekstrakurikuler. }\end{array}$ \\
\hline
\end{tabular}

\section{Partisipan kegiatan}

Partisipan kegiatan ini adalah 3 (tiga) orang guru dan 18 (delapan belas) siswa SD/MI Bahagia, Wonokromo, Surabaya. Salah satu guru juga merangkap sebagai Kepala Sekolah. Siswa yang terlibat termasuk siswa kelas 1 hingga kelas 6 . Terdapat 35 siswa secara keseluruhan, akan tetapi banyak siswa yang tidak selalu aktif mengikuti pelajaran setiap harinya. 


\section{Prosedur pelaksanaan}

Kegiatan I

Berikut ini adalah deskripsi beberapa kegiatan yang dilaksanakan.

Permainan edukasi pertama yang digunakan dalam kegiatan PKM ini adalah permainan menggunakan kartu kata. Adapun rancangan kegiatan yang dilakukan adalah sebagai berikut.

a. Siswa dibentuk dalam 4 kelompok, masing-masing terdiri dari 3 orang. Pada sesi pertama, 2 kelompok saling berkompetisi dengan aturan permainan sebagai berikut.

(1) Kartu huruf diletakkan dengan jarak 2,5 meter dari meja kelompok.

(2) Sebuah pertanyaan atau soal diberikan oleh instruktur. Jawaban peserta harus dibuat dalam bentuk susunan kartu huruf yang dengan tepat membentuk jawaban dari soal atau pertanyaan.

(3) Pertanyaan atau soal yang diberikan mencakup soal pengetahuan umum, dan matematika.

(4) Setelah mendiskusikan jawaban di dalam kelompok masing-masing, maka setiap anggota kelompok harus secara bergantian berlari untuk mengambil kartu huruf di meja yang diletakkan sekitar 2,5 meter jauhnya. Setiap anggota kelompok hanya dapat mengambil 1 huruf pada satu waktu.

(5) Kartu huruf yang diambil dibawa kembali ke meja kelompok dan diletakkan berurutan untuk membentuk jawaban.

(6) Pemenang ditentukan dari ketepatan jawaban dan kecepatan dalam menyelesaikan susunan huruf yang menyusun jawaban.

(7) Kelompok yang tertinggal diminta untuk menyelesaikan tugasnya hingga jawaban tersusun dengan tepat.

(8) Dua kelompok yang belum bertanding menjadi penyemangat bagi kelompok yang sedang bermain.

b. Setelah pemenang dari sesi pertama ditentukan, dua kelompok yang selanjutnya bertanding mengikuti aturan yang sama.

c. Pemenang dari sesi 1 dan sesi 2 ditandingkan lagi dengan aturan yang sama.

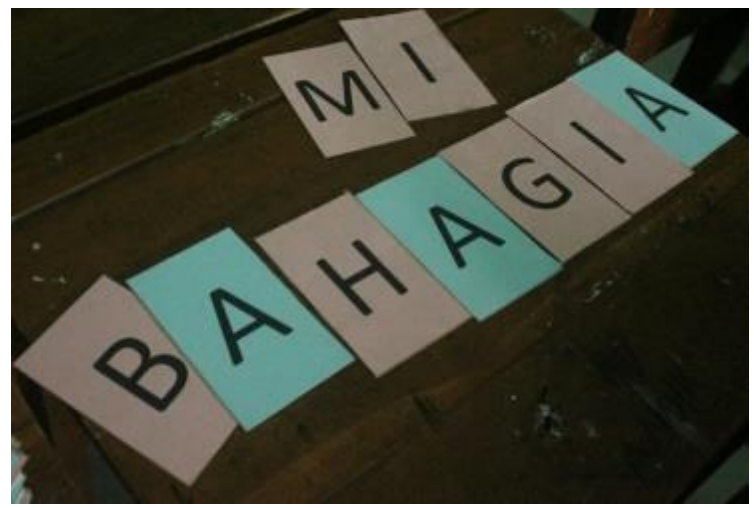

Gambar 1. Contoh kartu huruf yang digunakan

\section{Kegiatan 2}

Mendongeng atau storytelling merupakan aktivitas yang disarankan untuk meningkatkan perkembangan kognitif anak (Morrow, 1985). Dalam kegiatan ini, cerita yang digunakan adalah cerita tentang seorang anak laki-laki yang dijauhi oleh teman-temannya karena dianggap aneh dan tidak berbakat. Akan tetapi, anak ini sebenarnya memiliki hobi yang unik, yaitu menari. Anak ini secara diamdiam terus berlatih seorang diri, hingga akhirnya ia menjadi penari yang diakui oleh orang banyak. Inti dari cerita tersebut adalah untuk tidak menyerah pada keadaan dan lingkungan, serta pentingnya memiliki kepercayaan dan keyakinan diri. Kegiatan mendongeng disertai dengan kartu-kartu gambar.

Cerita yang lain adalah sebuah kisah mengenai 2 karakter yang hampir terjatuh ke dalam jurang. Untuk mencapai bagian atas tebing, keduanya harus bekerjasama dan saling mempercayai satu sama lain dengan cara menempelkan bagian punggung satu sama lain dan perlahan memanjat dengan irama yang sama hingga ke atas. Adapun 2 karakter yang diceritakan adalah 2 karakter yang saling bermusuhan pada awalnya. Salah satu dari karakter tersebut adalah raja yang dikutuk menjadi seekor unta, sementara karakter yang lain adalah seorang petani biasa yang pernah diusir sang raja ketika di istana. Pesan moral dari kisah ini adalah pentingnya kerjasama dalam hidup dan tidak membeda-bedakan dengan siapa kita berteman. 


\section{Kegiatan 3}

Pada kegiatan ini, siswa diajak untuk memiliki gambaran yang positif tentang diri mereka sendiri dan masa depan mereka. Siswa diajak untuk membayangkan diri mereka menjadi orang yang mereka inginkan dengan mata terpejam. Siswa diajak untuk membayangkan diri mereka dalam pakaian dokter, tentara, dan lain-lain sesuai cita-cita mereka. Siswa juga diajak untuk meneriakkan kata-kata motivasi, seperti "saya bisa"; "saya percaya". Siswa diajak menuliskan cita-cita mereka dan menempelkannya di kertas manila yang dibentuk dan digambari pohon yang besar. Masing-masing siswa menempelkan citacita mereka di gambar pohon tersebut dan ditempel di kelas. Siswa diminta membayangkan pohon tersebut tumbuh menjadi besar sebagaimana cita-cita mereka juga akan tumbuh seiring pertumbuhan mereka. Kegiatan ini merupakan implementasi sederhana dari pendekatan kognitif-behavior yang umum digunakan untuk mengubah cara pandang seseorang terhadap peristiwa, lingkungan, maupun diri sendiri (Bruning, Schraw, \& Norby, 2011).

\section{Hasil dan pembahasan}

Kegiatan yang dirancang dalam kegiatan ini dibuat dengan mempertimbangkan karakteristik siswa pada kelompok usia SD. Selain itu, tujuan untuk mendukung capaian akademik juga dipertimbangkan dan dimasukkan sebagai bagian dari materi yang diberikan. Kegiatan diberikan setiap minggu dengan melibatkan guru dan siswa. Hasil yang dapat diobservasi maupun dilaporkan oleh guru adalah meningkatnya partisipasi kedatangan siswa ke sekolah. Dari rata-rata 10 hingga 12 orang menjadi 15 hingga 18 orang tiap harinya.

Pada kegiatan pertama, siswa menunjukkan keaktifan dan antusiasme yang tinggi. Semua siswa berpartisipasi aktif. Selama mengunggu giliran, siswa juga tetap aktif memberi semangat pada kelompok yang sedang tampil. Beberapa siswa dapat menjawab pertanyaan yang diberikan dengan sangat baik, tanpa bantuan. Misalnya, pertanyaan mengenai ibukota Jawa Tengah, yang merupakan salah satu materi pengetahuan umum. Begitu pula dengan soal matematika. Beberapa siswa dapat menjawab dengan sangat baik soal-soal operasi matematika sederhana. Seorang siswa bahkan dapat membenarkan jawaban temannya yang keliru dan menunjukkan bagaimana soal tersebut seharusnya dipecahkan. Beberapa materi pokok yang ditingkatkan dalam kegiatan ini adalah pengetahuan matematika; pengetahuan tentang Negara meliputi nama kota, dasar Negara, dan segala sesuatu yang berhubungan dengan Negara; pengetahuan tentang ras; pengetahuan tentang suku; pengetahuan tentang agama; pengetahuan tentang warna; pengetahuan tentang antonim.

Sebagian besar siswa juga dapat memahami instruksi verbal yang diberikan mengenai aturan permainan. Hal ini sebenarnya menunjukkan kemampuan kognitif yang cukup memadai. Selain itu, tidak hanya memahami aturan permainan, tetapi juga mengikuti aturan permainan tersebut. Siswa juga dapat mengingatkan temannya ketika tidak melakukan sesuatu sesuai dengan aturan yang telah disampaikan dan disepakati.

Salah satu hal yang menarik adalah siswa ternyata memiliki rasa ingin tahu dan ketertarikan cukup besar terhadap berbagai materi pengetahuan umum. Siswa tidak hanya menjawab pertanyaan yang diberikan, tetapi juga dapat memunculkan pertanyaan yang menunjukkan meningkatnya pemahaman dan wawasannya. Hal tersebut dapat menjadi indikasi bahwa dengan metode yang berbeda, siswa dapat memiliki sikap yang berbeda terhadap proses pembelajaran. Hal ini juga salah satu yang didiskusikan tim dengan guru-guru pengajar di SD/MI Bahagia selama proses pendampingan.

Pada kegiatan kedua, siswa dapat mendengarkan cerita dengan baik dan perhatian. Setelah kegiatan dongeng selesai, selanjutnya siswa diberi berbagai pertanyaan terkait cerita yang telah disampaikan. Sebagian besar siswa dapat menjawab dengan baik yang menunjukkan kemampuan menangkap informasi yang cukup baik. Terdapat beberapa siswa yang menjawab tidak sungguh-sungguh dan lebih banyak bercanda, akan tetapi, mereka secara umum mengikuti kegiatan dengan baik. Siswa juga ditanya mengenai pesan moral yang ada di dalam cerita. Seorang siswa dapat menjawab dengan sangat baik, dimana ia mengatakan bahwa kita sebagai manusia harus saling tolong menolong dengan orang lain, juga harus bisa memaafkan orang lain. Siswa yang lain dapat menambahkan setelah diberi pertanyaan pancingan atau tambahan. Jawaban yang diberikan siswa antara lain, harus kerjasama, harus percaya dengan orang lain, tidak boleh bohong, dan harus saling menyayangi. Selain itu, dalam kegiatan ini yang penting juga adalah meningkatkan motivasi siswa agar memiliki kesadaran untuk mengubah diri dan mengambil langkah-langkah untuk melakukan perubahan. Hal tersebut diberikan sesudah kegiatan melalui pemberian instruksi dari tim.

Kegiatan ketiga, merupakan kegiatan yang secara khusus dirancang untuk meningkatkan motivasi siswa dan konsep dirinya. Pada awalnya siswa diminta menyebutkan cita-citanya. Terdapat dua siswa 
yang mengatakan ingin menjadi dokter, 1 orang ingin menjadi tentara, 1 orang menjadi perawat, dan 1 orang menjadi guru. Mereka lalu diminta untuk menutup mata dan membayangkan mereka sudah menjadi dokter, tentara, dan lain-lain sesuai cita-cita mereka. Saat membuka mata, mereka diminta menirukan cara berjalan tentara, dengan meneriakkan kata-kata "saya bisa" dan "saya percaya saya bisa". Mereka diminta mengatur postur tubuh dengan pundak tegap dan dada yang sedikit mendongak ke atas. Pada kegiatan ini, siswa mengikuti secara aktif dan antusias dengan bersemangat menirukan kata-kata instruktur, seperti "saya bisa", "saya hebat", dan "saya percaya". Semangat yang meningkat dapat dirasakan pada kegiatan tersebut. Tujuan kegiatan ini adalah meningkatkan motivasi dan konsep diri mereka agar menjadi lebih baik.

Berdasarkan uraian hasil di atas, dapat disimpulkan bahwa kegiatan ekstrakurikuler yang diterapkan pada PKM ini telah mencakup berbagai aspek perkembangan, antara lain sebagai berikut.

1. perkembangan kognitif, berupa peningkatan pengetahuan dan pemahaman. Soal ataupun pertanyaan yang diberikan disesuaikan dengan materi yang telah dipelajari siswa dan disesuaikan dengan perkembangan kognitifnya. Selain soal-soal yang menuntut pengetahuan, siswa juga diberi soal dalam bentuk cerita yang menuntut siswa untuk menangkap informasi yang ada di dalam cerita untuk dapat digunakan dalam pemecahan masalah.

2. perkembangan sosial-emosional, berupa peningkatan kepercayaan diri dan kerjasama tim. Siswa diharapkan mengungkapkan pendapat ataupun jawabannya secara verbal, dan masing-masing anggota kelompok memiliki tanggung jawab yang sama untuk menentukan jawaban yang tepat.

3. perkembangan moral, yaitu kemampuan siswa untuk mengikuti aturan dan bersikap adil terhadap sesama, menunggu giliran, dan saling memberi dukungan positif. Siswa diberi pemahaman mengenai aturan dan setiap siswa dilibatkan dalam menjaga aturan tersebut dijalankan. Dengan demikian, masingmasing siswa diharapkan mengembangkan rasa tanggung jawab dalam menegakkan aturan dan bersikap adil pada sesama. Selain itu, siswa juga dilatih untuk bersabar menunggu giliran dan saling memberi dukungan. Walaupun berkompetisi, siswa diberi pemahaman bahwa kerjasama tim sangat menentukan keberhasilan dan kompetisi yang ada tidak seharusnya memecah belah siswa.

4. perkembangan fisik-motorik, yaitu melakukan aktivitas fisik yang memerlukan koordinasi antara berbagai anggota tubuh, seperti kaki, tangan, penglihatan, dan pendengaran. Kegiatan permainan edukasi yang diterapkan mengharuskan siswa untuk berlari kecil, serta memilih satu di antara banyak kartu huruf yang tersedia. Hal tersebut diharapkan melatih koordinasi motorik dan kemampuan perseptual umum.

5. perkembangan bahasa, yaitu peningkatan keterampilan komunikasi, baik reseptif maupun ekspresif. Komunikasi reseptif dicapai melalui kemampuan siswa untuk memahami instruksi verbal yang diberikan, menangkap informasi dari cerita yang disampaikan, sedangkan kemampuan komunikasi ekspresif merupakan kemampuan siswa untuk mengungkapkan pendapat dan perasaan dengan cara yang dapat diterima secara sosial.

Menurut Depdikbud (1994:6) bahwa kegiatan ekstrakurikuler adalah kegiatan olahraga yang dilakukan di luar jam pelajaran tatap muka, dilaksanakan untuk lebih memperluas wawasan atau kemampuan peningkatan dan penerapan nilai pengetahuan dan kemampuan olahraga. Adapun menurut UU No.20 tahun 2003 tentang Sistem Pendidikan Nasional, disebutkan bahwa tujuan pendidikan nasioinal adalah untuk mengembangkan "potensi peserta didik agar menjadi manusia yang beriman dan bertakwa kepada Tuhan Yang Maha Esa, berakhlak mulia, sehat, berilmu, cakap, kreatif, mandiri, dan menjadi warga negara yang demokratis serta bertanggungjawab" (Permendikbud, 2013). Pengembangan potensi tersebut dicapai melalui kegiatan ekstrakurikuler. Kegiatan ini diharapkan dapat menjadi pelengkap ataupun tambahan untuk memenuhi kebutuhan pengembangan peserta didik yang berbeda-beda yang belum secara optimal terakomodir dalam kegiatan ekstrakurikuler.

Permendikbud (2013) menyebutkan bahwa berbagai hal yang dapat dipelajari siswa dalam kegiatan ekstrakurikuler antara lain adalah kemampuan komunikasi, bekerjasama dengan orang lain, serta menemukan dan mengembangkan potensinya, selain juga memberikan manfaat sosial yang besar. Lebih jelasnya, definisi dari kegiatan ekstrakurikuler menurut Permendikbud (2013) adalah sebagai berikut, "Kegiatan pendidikan yang dilakukan oleh peserta didik di luar jam belajar kurikulum terstandar sebagai perluasan dari kegiatan kurikulum dan dilakukan di bawah bimbingan sekolah dengan tujuan untuk mengembangkan kepribadian, bakat, minat, dan kemampuan peserta didik yang lebih luas atau di luar minat yang dikembangkan oleh kurikulum."

Berdasarkan uraian tersebut dapat disimpulkan bahwa kegiatan ekstrakurikuler dianggap penting sebab hal-hal berikut, (1) merupakan amanah UU; (2) prinsip bahwa pendidikan harusnya bersifat holistik atau menyeluruh; (3) prinsip perkembangan bahwa masing-masing anak adalah unik dengan potensi yang berbeda-beda, sehingga tidak dapat seluruhnya diakomodir melalui kegiatan kurikuler yang cenderung homogen; (4) adanya tuntutan untuk masa depan anak. Dengan demikian, jelaslah bahwa 
kegiatan ekstrakurikuler bukan sekedar kegiatan tambahan saja, melainkan kegiatan yang perlu dipersiapkan dengan baik, sebagaimana kegiatan kurikuler.

Hapsari, Widodo, dan Setyawan (2010) menemukan bahwa minat mengikuti kegiatan ekstrakurikuler berhubungan dan berkontribusi terhadap tingkat intensi delikuensi ataupun kenakalan siswa. Sumber yang sama menyebutkan bahwa siswa yang memiliki minat untuk terlibat dalam kegiatan ekstrakurikuler berarti memiliki kesadaran dan keinginan untuk terlibat dalam kegiatan-kegiatan yang positif. Observasi terhadap siswa SD/MI Bahagia menunjukkan adanya beberapa masalah dalam perilaku dan emosional. Latar belakang sosial ekonomi siswa dapat menjadi penyebab dari masalah tersebut. Lingkungan sosial yang kurang kondusif juga dapat menjadi penghambat perkembangan sosial-emosional yang optimal. Oleh sebab itu, memahami perilaku anak atau siswa tidak bisa terlepas dari pendekatan sosial dan budaya dimana siswa itu tinggal (John-Steiner \& Mahn, 1996).

Sebagaimana dijabarkan di latar belakang, permasalahan utama yang dihadapi adalah sikap negatif siswa terhadap sekolah dan proses belajar. Sikap negatif ini berdampak pada motivasi yang rendah untuk datang ke sekolah ataupun mengikuti pelajaran dengan aktif, serta kurang baiknya hubungan dengan guru-guru pengajar. Sikap negatif siswa dapat disebabkan oleh banyak hal, salah satunya adalah sikap guru terhadap perilaku siswa. Berdasarkan observasi, guru cenderung bersikap negatif terhadap perilaku negatif siswa. Artinya guru cenderung menghadapi siswa dengan perilaku yang sama-sama negatif, padahal sikap guru terhadap siswa berpengaruh besar dalam membentuk sikap siswa terhadap sekolah maupun pembelajaran (Gibson \& Chase, 2002; Wentzel, 1997). Lebih lanjut lagi, Skinner and Belmont (1993) menemukan bahwa sikap dan keterlibatan guru terhadap siswa akan dikomunikasikan secara sadar maupun tidak kepada siswa dan akan berpengaruh signifikan terhadap pengalaman siswa di sekolah maupun pembelajaran. Wentzel (1998) juga menemukan bahwa ketika siswa merasa mendapat dukungan dari orangtua, siswa akan memiliki minat terhadap hal-hal yang berhubungan dengan sekolah dan orientasi tujuan yang lebih baik dibandingkan siswa yang tidak merasa mendapat dukungan orangtua yang memadai.

Faktor lingkungan juga dianggap memiliki pengaruh cukup besar terhadap sikap siswa terhadap sekolah. Battistich, Solomon, Kim, Watson, and Schaps (1995) menemukan beberapa hal terkait hubungan antara perasaan siswa terhadap komunitas sekolah, tingkat kemiskinan, dengan sikap siswa, motif, keyakinan, dan perilaku. Sumber yang sama menyebutkan bahwa dalam sekolah yang sama, maka perasaan siswa terhadap komunitas sekolah memiliki hubungan signifikan dengan sikap, motif, keyakinan, dan perilaku siswa. Selain itu, ditemukan pula indikasi bahwa arah hubungan positif paling kuat dari faktor komunitas sekolah terjadi pada sekolah-sekolah yang memiliki populasi siswa yang paling kurang beruntung dari segi latar belakang sosial ekonomi keluarga (Battistich et al., 1995). Artinya makin negatif persepsi siswa terhadap komunitas sekolah maka semakin negatif pula sikap, motif, keyakinan, dan perilaku siswa tersebut, terutama pada sekolah-sekolah dengan latar belakang sosial ekonomi yang rendah. Hal tersebut diperkuat lagi dengan temuan penelitian yang menyebutkan bahwa sekolah-sekolah dimana siswa memiliki perasaan komunitas sekolah yang lebih tinggi, akan cenderung memiliki rata-rata perilaku siswa bermasalah yang lebih rendah dibandingkan sebaliknya (Battistich \& Hom, 1997). Dengan demikian, kemampuan sekolah untuk menciptakan lingkungan yang membuat siswa merasa nyaman dan aman di dalamnya dapat memiliki pengaruh signifikan terhadap sikap dan perilaku siswa.

Karakteristik siswa SD/MI Bahagia yang sebagian besar dari golongan ekonomi bawah, dapat menjadi penghambat bagi keinginan mereka untuk maju. Siswa-siswa ini perlu sering mendapat motivasi bahwa mereka dapat mencapai cita-cita mereka. Kondisi sekolah dan Sumber Daya Manusia (SDM) yang ada sering dijadikan alasan oleh pihak sekolah untuk tidak memberi pelayanan yang optimal pada siswa. Padahal melakukan kegiatan ekstrakurikuler dapat dilakukan dengan sarana prasarana yang minimal. Dengan demikian, sekolah perlu memberikan kesempatan pada siswa untuk aktif di kegiatan ekstrakutikuler sesuai dengan minat mereka. Hastuti (2008) menjelaskan manfaat dari kegiatan ekstrakurikuler antara lain adalah memberikan keterampilan tambahan yang tidak didapat dari mata pelajaran di kelas, seperti sikap mental dan dedikasi yang baik terhadap profesinya kelak.

Pelaksanaan kegiatan telah dilakukan dengan memberikan kegiatan ekstrakurikuler kepada siswa SD MI Bahagia, sementara guru-guru mengobservasi. Kegiatan dirancang dengan menggunakan RPS (Rencana Pembelajaran Semester) sebagaimana kegiatan kurikuler. Membuat rancangan di dalam RPS memudahkan proses pelaksanaan dan dapat memberi contoh bagi perencanaan kegiatan selanjutnya. Siswa, terutama terlihat antusias dalam mengikuti kegiatan. Siswa-siswa SD/MI Bahagia walaupun dengan berbagai keterbatasan, ternyata memiliki cita-cita yang tinggi dan optimisme terhadap masa depan. Beberapa siswa misalnya, bercita-cita menjadi dokter, tentara, dan polisi. Melalui kegiatan ekstrakurikuler siswa-siswa memiliki kesempatan untuk menggali potensi dan minat mereka yang kerap kali tidak terakomodasi dalam kegiatan kurikuler. Dalam kegiatan ekstrakurikuler ini juga diketahui bahwa siswa dapat memahami materi dengan cukup baik ketika diberikan dengan cara yang berbeda. 
Pendekatan konvensional dalam pembelajaran, seperti ceramah 1 (satu) arah dipandang tidak lagi sesuai dengan tuntutan pendidikan. Hasil penelitian ini juga sejalan dengan penelitian Nuri (2016) yang mneunjukkan adanya pengaruh sangat kuat dan signifikan antara kegiatan ekstrakurikuler terhadap perkembangan life skills peserta didik.

Kurikulum 13 yang mulai diimplementasikan secara merata, sebenarnya menginginkan pendidikan anak yang komprehensif mencakup berbagai aspek perkembangannya. Kurikulum 2013 memberi penekanan yang kurang lebih sama antara kegiatan kurikuler dengan ekstrakurikuler. Hal tersebut dapat dilihat dalam Permendikbud Nomor 81A tentang implementasi kurikulum 2013, lampiran III. Pada bagian pendahuluan, dijelaskan bahwa kegiatan ekstrakurikuler dapat dianggap sebagai jembatan untuk memenuhi kebutuhan siswa yang berbeda-beda, terutama ditinjau dalam berbagai aspek perkembangan (Permendikbud, 2013). Lebih utamanya lagi, penelitian-penelitian menunjukkan pentingnya peran sekolah dalam menciptakan lingkungan kondusif bagi siswa, dimana hal tersebut dapat berdampak positif bagi sikap dan perilaku siswa terhadap sekolah dan proses pembelajaran.

Apresiasi khusus kami berikan kepada Tim Bakti Psikologi Unesa, yang telah membantu penyelenggaraan kegiatan ini. Ucapan terimakasih kami berikan kepada pihak SD/MI Bahagia, Wonokromo, Surabaya atas partisipasinya sebagai mitra dalam kegiatan ini, yang pada saat artikel ini ditulis telah bergabung dengan sekolah lain, sebab dianggap tidak memenuhi persyaratan minimal sekolah..

\section{Simpulan dan saran}

Siswa dan guru di SD/MI Bahagia telah mengikuti kegiatan PKM yang diselenggarakan dengan aktif dan antusias. Siswa merasa mendapat pengalaman belajar baru yang jarang mereka dapatkan dari sekolah. Siswa secara umum menjadi lebih bersemangat untuk datang ke sekolah dan mengikuti pelajaran. Guru-guru juga merasa lebih bersemangat karena melihat perubahan dari sikap siswa. Salah satu temuan dari kegiatan ini adalah (1) sikap guru terhadap siswa sangat berpengaruh terhadap sikap siswa terhadap sekolah dan pembelajaran, begitu pula sebaliknya, (2) sekolah yang dapat menyediakan lingkungan yang positif bagi siswa diduga memiliki pengaruh terhadap sikap dan perilaku siswa, dan (3) siswa-siswa dengan prestasi belajar maupun sikap dan motivasi yang rendah, dapat diatasi salah satunya dengan mengajarkan pelajaran dengan cara yang berbeda yang menarik minat mereka. Dengan demikian, saran bagi kegiatan selanjutnya adalah memberikan perhatian lebih pada faktor sekolah sebagai komunitas atau sistem yang berpengaruh besar pada perilaku siswa, memberikan perhatian terhadap kemampuan instruksional guru lebih besar daripada kemampuan bawaan siswa (seperti inteligensi) dalam mengatasi permasalahan akademik yang rendah, serta memberikan perhatian pada faktor-faktor yang dapat dikontrol daripada yang tidak dapat dikontrol, dalam upaya memahami prestasi belajar siswa.

\section{Daftar Rujukan}

Ailwood, J. 2003. Governing early childhood education through play. Contemporary Issues in Early Childhood, 4(3), 286-299.

Battistich, V., \& Hom, A. 1997. The relationship between students' sense of their school as a community and their involvement in problem behaviors. American journal of public health, 87(12), 1997-2001.

Battistich, V., Solomon, D., Kim, D., Watson, M., \& Schaps, E. 1995. Schools as communities, poverty levels of student populations, and students' attitudes, motives, and performance: A multilevel analysis. American educational research journal, 32(3), 627-658.

Bruning, R.H., Schraw, G.J., \& Norby, M.M. 2011. Cognitive Psychology and Instruction 5th ed. New Jersey: Pearson.

Gibson, H.L., \& Chase, C. 2002. Longitudinal impact of an inquiry - based science program on middle school students' attitudes toward science. Science education, 86(5), 693-705.

Hapsari, U.R., Widodo, P.B., \& Setyawan, I. 2010. Hubungan antara minat mengikuti kegiatan ekstrakurikuler dengan intensi delikuensi remaja pada siswa Sekolah Menengah Kejuruan (SMK) di Kota Semarang. Jurnal Fakultas Psikologi. 
Hastuti, T.A. 2008. Kontribusi ekstrakurikuler bola basket terhadap pembibitan atlet dan peningkatan kesegaran jasmani. Jurnal Pendidikan Jasmani Indonesia, 5(1).

John-Steiner, V., \& Mahn, H. 1996. Sociocultural approaches to learning and development: A Vygotskian framework. Educational psychologist, 31(3-4), 191-206.

Morrow, L.M. 1985. Retelling stories: A strategy for improving young children's comprehension, concept of story structure, and oral language complexity. The Elementary School Journal, 85(5), 647-661.

Nuri, Febi Putri, Berchah Pitoewas, Hermi Yanzi. 2016. Pengaruh Kegiatan Ekstrakurikuler Terhadap Perkembangan Life Skills Peserta Didik Sma Yp Unila. Jurnal fakultas ilmu pendidikan Unila.

Permendikbud. 2013. 81a Tahun 2013 tentang implementasi kurikulum 2013. Jakarta.

Rieber, L.P. 1996. Seriously considering play: Designing interactive learning environments based on the blending of microworlds, simulations, and games. Educational technology research and development, 44(2), 43-58.

Skinner, E.A., \& Belmont, M.J. 1993. Motivation in the classroom: Reciprocal effects of teacher behavior and student engagement across the school year. Journal of educational psychology, 85(4), 571.

Ubaidah, Siti. 2014. Manajemen Ekstrakurikuler Dalam Meningkatkan Mutu Sekolah. Jurnal online.

Wentzel, K.R. 1997. Student motivation in middle school: The role of perceived pedagogical caring. Journal of educational psychology, 89(3), 411.

Wentzel, K.R. 1998. Social relationships and motivation in middle school: The role of parents, teachers, and peers. Journal of educational psychology, 90(2), 202. 